Revue DE MLGRopalénTUlogit

Vol. $43, \mathbf{n}^{0} 3$, septembre 2000 , pp. 381-391

\title{
INTEGRATED BIOSTRATIGRAPHY ACROSS THE YPRESIAN/LUTETIAN BOUNDARY AT AGOST, SPAIN
}

\author{
BIOSTRATIGRAPHIE INTÉGRÉE DE LA TRANSITION \\ YPRÉSIENILUTÉTIEN D'AGOST, ESPAGNE
}

\author{
by Eustoquio MOLINA*, Vlasta COSOVIC**, Concepción GONZALVO* \\ and Katharina VON SALIS***
}

\begin{abstract}
The integrated hiostratigraphy of a $112 \mathrm{~m}$ thick exposed section near Agost (Southern Spain) was studied to assess its suitability as a Global Stratotype Section and Point (GSSP) for the Early/Middle Eocene (Ypresian/Lutetian) Boundary. This section consists of marls interbedded with calcarenites and detrital turbidite layers deposited in a hemipelagic environment. Planktic foraminifera provided good biozonation from P8 through P11 Zones. The calcareous nannofossil Zones NP13 through NP16, respectively CP11 through CP14a, could be distingurshed. The larger foraminiferal Zones SBZ12 to SBZ14 could tentatively be distinguished. The base of the $H$. nuttalli (P.10) Zone, which is often used to set the boundary between the Lower and the Middle Eocene (Ypresian/Lutetian) falls at a facies change. The Agost Section can be used as a GSSP only if no beller section is found.

RÉsumé. - La biostratıgraphe intégrée d"une coupe mesurant $112 \mathrm{~m}$ d'épaisseur exposée près d'Agost dans le Sud de l'Espagne a été étudiée afin d'évaluer son adéquation comme "Global Stratotype Section and Point (GSSP)" pour la limite Eocène inférieur/moyen (Yprésien/Lutétien). La coupe est composée de marnes intercalées de calcarénites et couches détritiques turbidiques déposées dans un environnement hémipélagique. Les foraminifères planctoniques permettent une bonne biozonation depuis la zone P8 à P11. Pour les nannofossiles calcaires on peut distinguer les zones NP13 à NP16 et respectivement CP11 à CP14a. Pour les grands foraminifères il est possible de distinguer, hien que sans beaucoup de précision, les zones SBZ12 à SBZ14. La base de la zone à $H$. nuttalli (P10), qui est généralement utilisée pour marquer la limite cntre l'Eocéne inférieur et moyen (Yprésien/Lutétien) coïncide avec un changement de faciès. Par conséquent la coupe d'Agost pourrait être choisie comme GSSP si aucune coupe plus appropriée n’est trouvée. Spain.

Key-words : Ypresian - Lutetian - Eocene - Foraminifera - Calcareous Nannofossils - Biostratigraphy - Chronostratigraphy -

Mots-clés : Yprésien - Lutétien - Eocène - Foraminfères - Nannofossiles calcaires - Biostratigraphie - Chronostratigraphie Espagne.
\end{abstract}

\section{INTRODUCTION}

The Agost section is very suitable for an integrated biostratigraphical study across the Early/Middle Eocene (Ypresian/Lutetian) boundary since it is very rich in several microfossil groups. It was first studied by Colom (1954) and Von Hillebrandt (1974, 1976) in the Betic Cordillera. Different biostratigraphical and micropaleontological aspects were also analysed by Márquez (1975, 1983, 1991), Cremades (1982), Márquez and Usera (1984) and Gonzalvo and Molina (1998), but these data have not been integrated in a detailed chronostratigraphical framework.

The Agost section is located at Lomas de la Beata, $1 \mathrm{~km}$ North of the village of Agost (Alicante province, Southeast Spain) near several small abandoned quarries (Fig. 1). The lithology consists of marls with interbedded calcarenite strata. The middle part of the section is very detrital. The hemipelagic marls

* Departamento de Ciencias de la Tierra. Universidad de Zaragoza. 50009 Zaragoza. Spain.
* Department of Geology and Paleontology. University of Zagreb. 10000 Zarreb. Croatia.

**** Geological Institute ETH Zentrum. 8092 Zürich. Switzerland. 


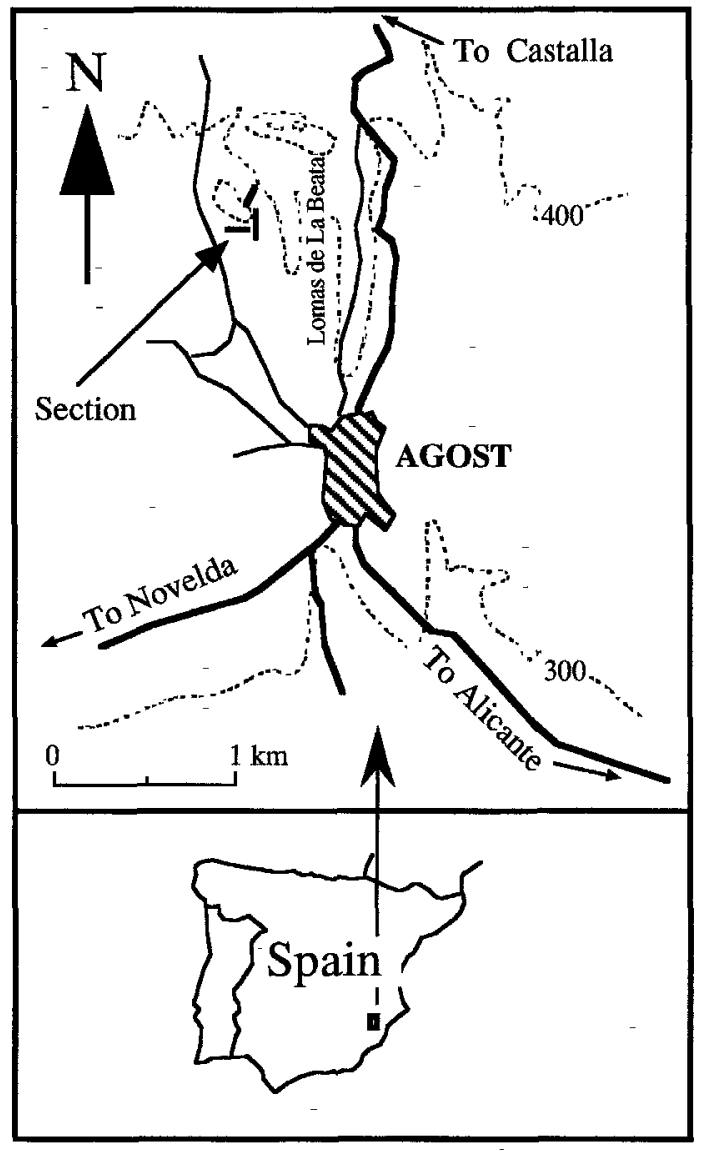

Fig. 1. - Geographical location of the Agost section. Localisation géographique de la coupe d'Agost.

are rich in planktic foraminifera and calcareous nannofossils, whereas some of the turbiditic calcarenite strata contain abundant larger foraminifera.

The biostratigraphy of the Ypresian/Lutetian is needed to define its boundary stratotype. Precise boundary placement depends on establishing and correlating different biozonations. In this paper we tried to establish an accurate integrated biostratigraphy by studying the most important microfossil groups in detail, with the final aim of improving the chronostratigraphy across the Early/Middle Eocene.

\section{PLANKTIC FORAMINIFERA}

The planktic foraminifera were obtained by washing autochtonous marls and quantitatively examined using a modified Otto microsplitter. This analysis was based on representative splits of 400 or more specimens in the size fraction larger than 100 microns. The rest of each sample was scanned for rare species. The planktic foraminiferal assemblages were moderately to well-preserved and very diversified. They were generally characteristic of subtropical to temperate latitudes and deposited in a bathyal environment sporadically affected by turbidity currents, including some reworked fossils.

Agost planktic foraminifera were first studied by Von Hillebrandt $(1974,1976)$ who defines the Planorotalites palmerae Biozone. A more detailed study by Márquez $(1975,1983,1991)$ and Márquez and Usera (1984) relegate this zone to a subzone. Cremades (1982) establish a similar biozonation but with an "Eoglobigerina" frontosa Biozone instead of the $P$. palmerae Biozone. A new detailed biozonation across the Lower-Middle Eocene transition at Agost and Alamedilla sections (Gonzalvo and Molina, 1998) has the Acarinina pentacamerata Zone subdivided in the Acarinina pentacamerata Subzone, the Subbotina boweri Subzone and the Truncorotaloides praetopilensis Subzone and the Hantkenina nuttalli Zone including the Hantkenina nuttalli Subzone and the Globigerapsis subconglobata Subzone. These biozones and subzones are defined by the first occurrence (FO) of the nominated taxon, except the base of the G. subconglobata Subzone that is defined by the FO of Globigerapsis index (which is easily recognizable since its FO marks the beginning of the typical Middle Eocene assemblages). This biozonation can be correlated with the upper part of zones P8 through P11 of the standard zonation in Berggren et al. (1995). Nevertheless, the base of Zone P9 was not placed precisely since only one sample had $P$. palmerae and the base of Zone P1I was not recognized becanse Globigerapsis kugleri was not found (Fig. 2).

Seven species ( $15 \%$ of all species) gradually disappeared in the Acarinina pentacamerata Zone and five species $(11 \%)$ in the Hantkenina nuttalli Zone, constituting a clear background extinction pattern. During this extinction others species appeared and diversity greatly increased (22 new species and 12 extinct). Appearance was not completely gradual since the diversity rate accelerated at the base of the Hantkenina nuttalli Zone, where a cladogenesis process affected the genera Truncorotaloides and Hantkenina, with $57 \%$ of the species evolving at this level. Another increase in diversity was evident in the S. boweri Subzone, with $43 \%$ of the appearances. In general, the diversity increased from 24 species at the base of the section to 33 at the top (a $27 \%$ increase; Fig. 2). 


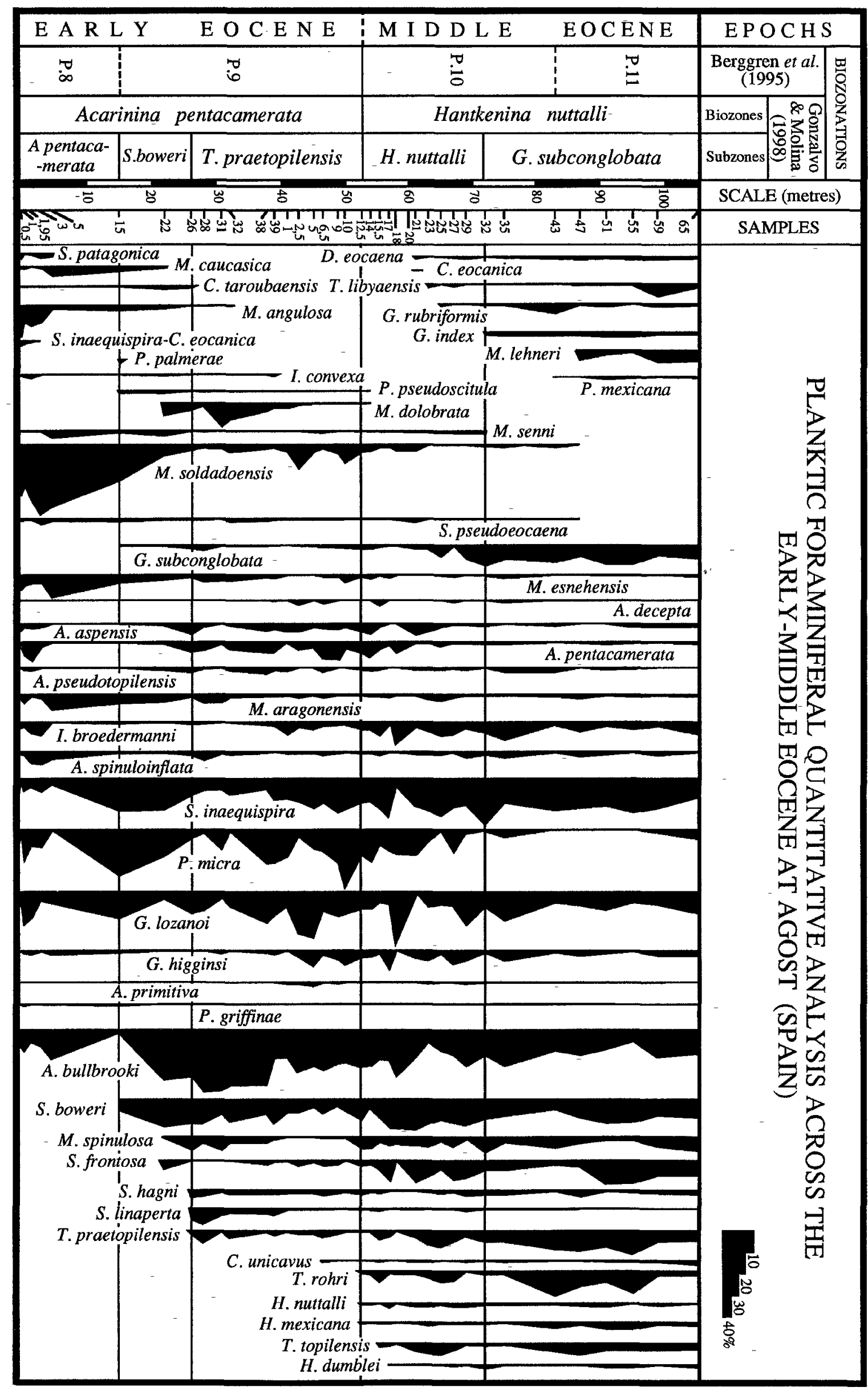

Fig. 2. - Planktic foraminiferal biostratigraphy and relative abundance.

Biostratigraphie et abondance relative de foraminiferes planctoniques. 
The increase in diversity across the Early/Middle Eocene boundary was characterized by the appearance of low latitude dwellers, mainly from the base of the Hantienina nuttalli Biozone. This could be the consequence of an increase in seawater temperature, in turn related to a rise in sea level since the sedimentation became more pelagic and marls were the dominant lithology.

\section{CALCAREOUS NANNOFOSSILS}

Simple smear slides were prepared for 45 samples (Fig. 3 and 4) and studied under light microscope at 1000x magnification. The calcareous nannofossil content varied from rare to common or abundant and the preservation ranged from poor to moderate/good.

The classical calcareous nannofossil zonation was difficult in this section. Markers from Martini (1971) and Okada and Bukry (1980) were either not found or too rare to be used with confidence. In addition, the ranges in Aubry (1983) and Steurbaut (1986, 1988) for additional markers from (mainly) Northern Europe seemed to be only partly useful to subdivide the section and assign ages to the calcareous nannofossil assemblages at Agost.

Discoaster sublodoensis, the marker for the lower boundary of NP14 in Martini (1971), was only found in one sample. Nannotetrina fulgens and Rhabdosphaera gladius, the zonal markers for NP15, were not found. The NP14/15 boundary was thus set in the interval above the $F O$ of $S$. furcatolithoides and below the $\mathrm{FO}$ of $\mathrm{S}$. gigas and no attempt was made to indicate the position of the NP15/16 boundary (Fig. 4). The presence of $C$. solitus up to the uppermost sample assigned the top of the section to NP16.

Two of the zonal markers in Bukry and Okada (1980), Rhabdosphaera inflata and Nannotetrina fulgens, were not found (Sullivania gigas, Discoaster bifax and Reticulofenestra umbilicus were present). The total range of $C$. gigas defined the subzone CP13b and the FO's of R. umbilicus and D. bifax the base of CP14a. The top of CP14a was defined by the LO of both Chiasmolithus solitus and D. bifax, while the LO of Chiasmolithus grandis defined the top of CP14b. S. gigas was only found in two samples (at 21 and 38), thus marking the interval of CPl3b. Reticulofenestra species are difficult to use for biostratigraphy. At Agost, Reticulofenestra dictyoda and $R$. coenura (both $<$ microns) were present almost from the bottom of the calcarenite interval. Larger forms ( $>10$ microns) assigned to $R$. umbilicus appeared occasionally from sample 21 onwards and consistently above 43 . This was considered the base of CP14a since D. bifax only appeared at 43 (whose highest occurrence was in 51). C. solitus was still present in the uppermost sample with a reasonable assemblage and the whole interval was assigned to CP14a. The presence of Campylosphaera dela, a species that usually disappears in CP14a, supports this assignment.

Steurbaut (1988) subdivided NP14 into 4 subunits using additional calcareous nannofossils. Unit XI at the bottom of NP14 is defined by the FO of Lanternithus minutus, Discoaster bifax, Discoaster wemmelensis and Zygrhablithus crassus. We found all of these, if $Z$. crassus is regarded as a synonym of $Z$. bijugatus (which has an older first occurrence than NP14 in this section). Of the three remaining species, D. wemmelensis was the first to appear (at 29.00) followed by $D$. bifax and L. minutus (at 43.00) in an interval regarded as younger than NP14, based on the presence of $S$. gigas. Aubry (1983) finds the above three forms together in the upper part of NP14. The determination of $D$. bifax by several authors is shown by Wei and Wise (1989) to include Discoaster praebifax, a new form with a similar diameter but nearly twice as many rays and only one prominent central stem, as opposed to the two stems of $D$. bifax (they also report $D$. praebifax from $\mathrm{CP} 12$ and CP13). If the base of Steurbaut's (1988) unit XI is at the FO of $D$. wemmelensis, it would lie above the FO of Discoaster saipanensis, one of the three species defining the base of unit XII. The forms appearing at the base of unit XIII include Sphenolithus furcatolithoides and three forms not found at Agost. Both Aubry (1989) and Perch-Nielsen (1985) give the range of Sphenolithus furcatolithoides as NP15 and NP16, while Aubry (1983) only reports it from NP16. S. furcatolithoides (or a very similar form?) was found in several samples considerably below the first occurrence of $D$. wemmelensis (which defines the base of unit XI and is usually considered to appear in CP12b or the upper part of NP14), far below where it appears at Agost. This suggests that the subdivision used by Steurbaut (1988) cannot be applied at Agost. The NP/CP subdivision shown in Fig. 3 and 4 is thus only tentative and we stress that other interpretations of the data are possible.

Modest reworking of Cretaceous coccoliths is present in most samples with the possible exception of $10.00,17.0$ and 18.0 (Fig. 5). As usual, Watznaueria barnesae, a species ranging through the whole Cretaceous, is the most commonly reworked form. It is closely followed by various Nannoconus species, a 
$=0$

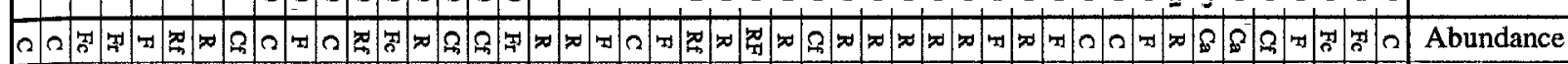

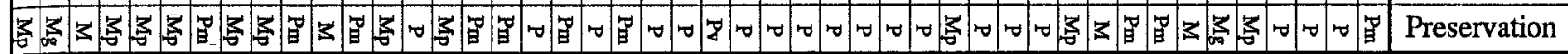

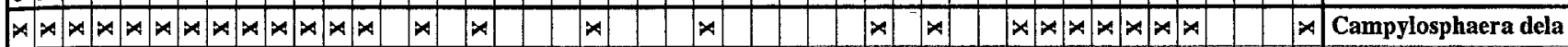

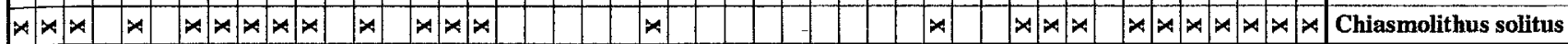

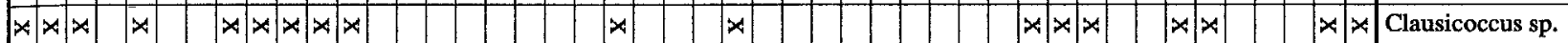

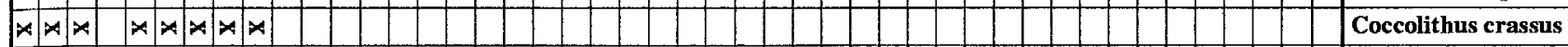

$x \times x \times x \times x \times x \times x \times x \times x \times x \times x \times x \times x \times x \times x \times x \times x$ Coccolithus eopelagicus

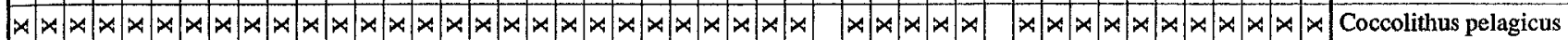

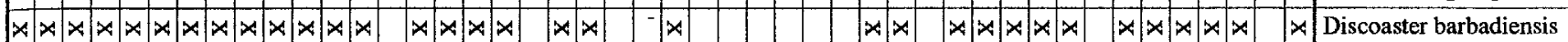

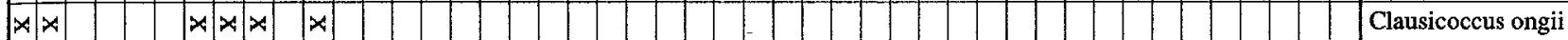

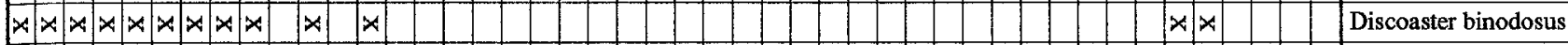

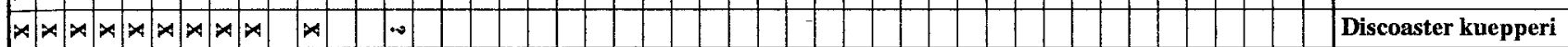

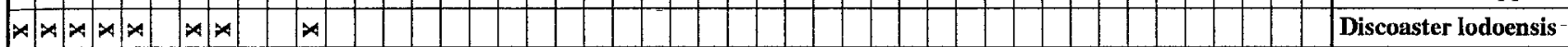

$\times x \times x \times x \times x \times x \times x \times x \times x \times x \times x \times x \times x \times x \times x \times x \times x \times x \times x$ Ericsonia formosa

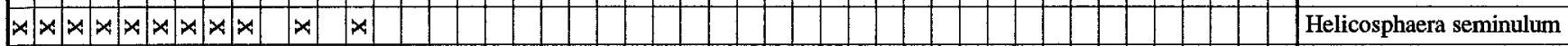

$x \times x \times x \times x \times x \times x \times x \times x \times x \times x \times x \times x \times x \times x \times x \times x \times x \times x \times x \times x \times x$ Prinsiaceae<ca $6 \mu$

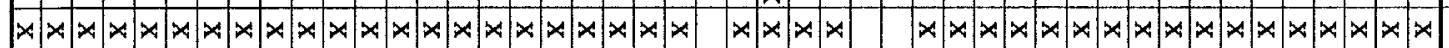

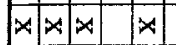

$x x x \quad x \quad x$

Sphenolithus moriformis

$x \mid x$

$x \quad x D$ D

Sphenolithus editus

Sphenolithus orphanknollii

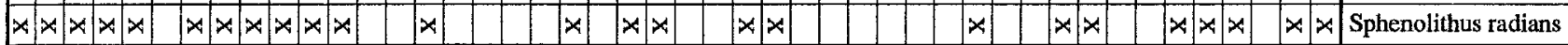

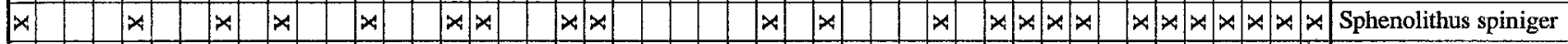

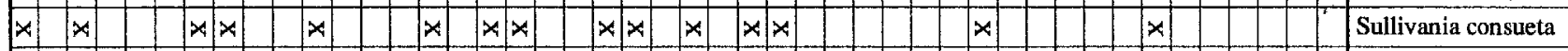

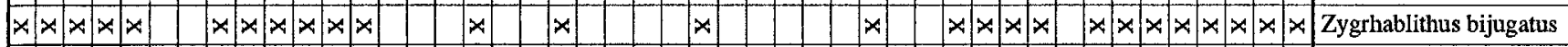

$x \times x \times x \times x \times x \times x \times x$ X $x \times x$ Cyclicargolithus floridanus

$x \times x \times x \times x|x| x$

Girgisia gammation

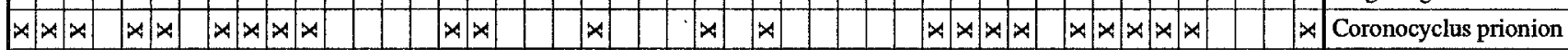

$x \times x \times x \times x \times x x_{x} \times x$ Discoaster sp. 6 arms

$x \mid x$

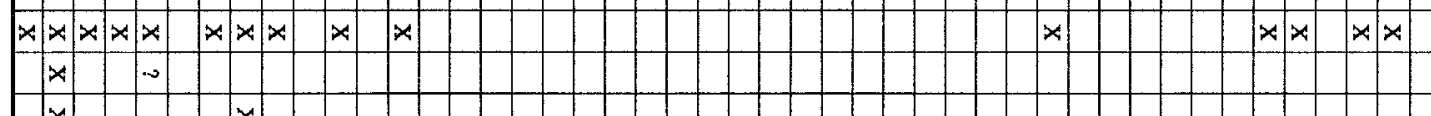

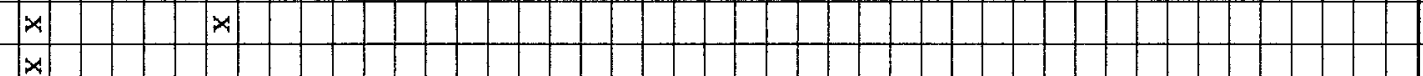

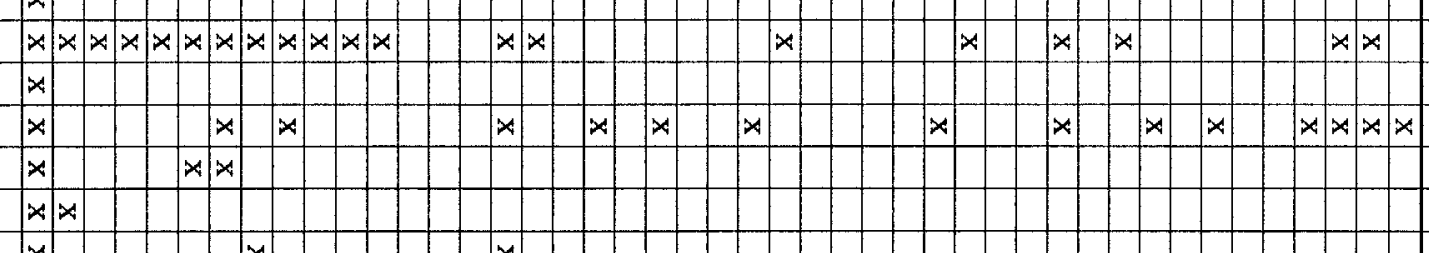

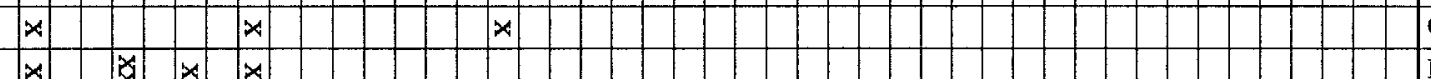

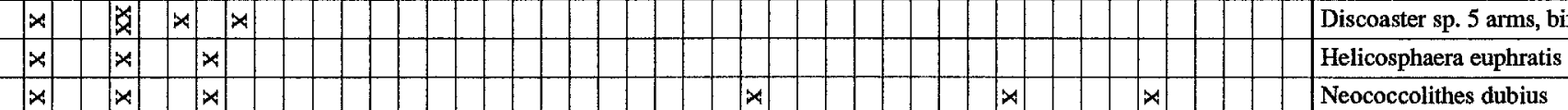

\begin{tabular}{|c|c|c|c|c|c|c|c|c|c|c|c|c|c|c|c|c|c|c|c|}
\hline$x$ & & $x$ & $x$ & & & & & & & & & $x$ & & & $x$ & $x$ & & & Neococcolithes dubius \\
\hline$x$ & $x \times x$ & $|x|$ & $x$ & $x$ & $x \mid x$ & $x|x|$ & $|x|>$ & & \begin{tabular}{|l|l|l|}
$x$ & $x$ & $x$ \\
\end{tabular} & & & $x$ & $x$ & 4 & $x$ & $x$ & $x$ & $x \mid x$ & Pontosphaera sp. \\
\hline$x$ & $x$ & $x$ & & $x$ & & $x|x|$ & $x>$ & $x$ & $x$ & $\sqrt[x]{x}$ & $x$ & $x$ & $x \mid x$ & $x x$ & $x \times x$ & $x \times$ & $x$ & & Reticulofenestra dictyoda $(<11 \mu)$ \\
\hline$x$ & & & & $x$ & & & & & & & & & & & & & & & Blackites morionum \\
\hline$x$ & & & & $x$ & & & & & 造运a & it & 齐 & 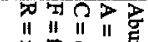 & & & & & & $x$ & Neococcolithes minutus \\
\hline$x$ & & & $\sim$ & & & & & $\infty$ & 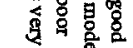 & & 葛 & 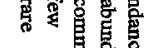 & $x$ & $4 . \omega$ & $\infty$ & $x$ & $x$ & & Striatococcus pacificanus \\
\hline$x$ & $x$ & $x \mid$ & $x$ & & & & & & & & & & & & & & & & Blackites trochus \\
\hline$x$ & $x$ & $\$ x$ & 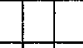 & & $x$ & & $x$ & $x$ & & & & & & & $x \times$ & $x$ & & & Blackites sp. \\
\hline$x$ & $x$ & & $x$ & & $x$ & & & & & & & & & & & & & & Lophodolithus sp. \\
\hline$x$ & & & 1 & & & $x$ & & $|x| x \mid$ & $x$ & $x \mid$ & & & $x$ & & $x$ & $x \mid x$ & & & Braarudosphaera bigelowii \\
\hline & & & $\bar{\omega}$ & & & & & 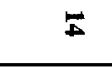 & & & & I & & $\sqrt{n}$ & & & & 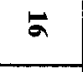 & NP - Zonation Martini, 1971 \\
\hline
\end{tabular}




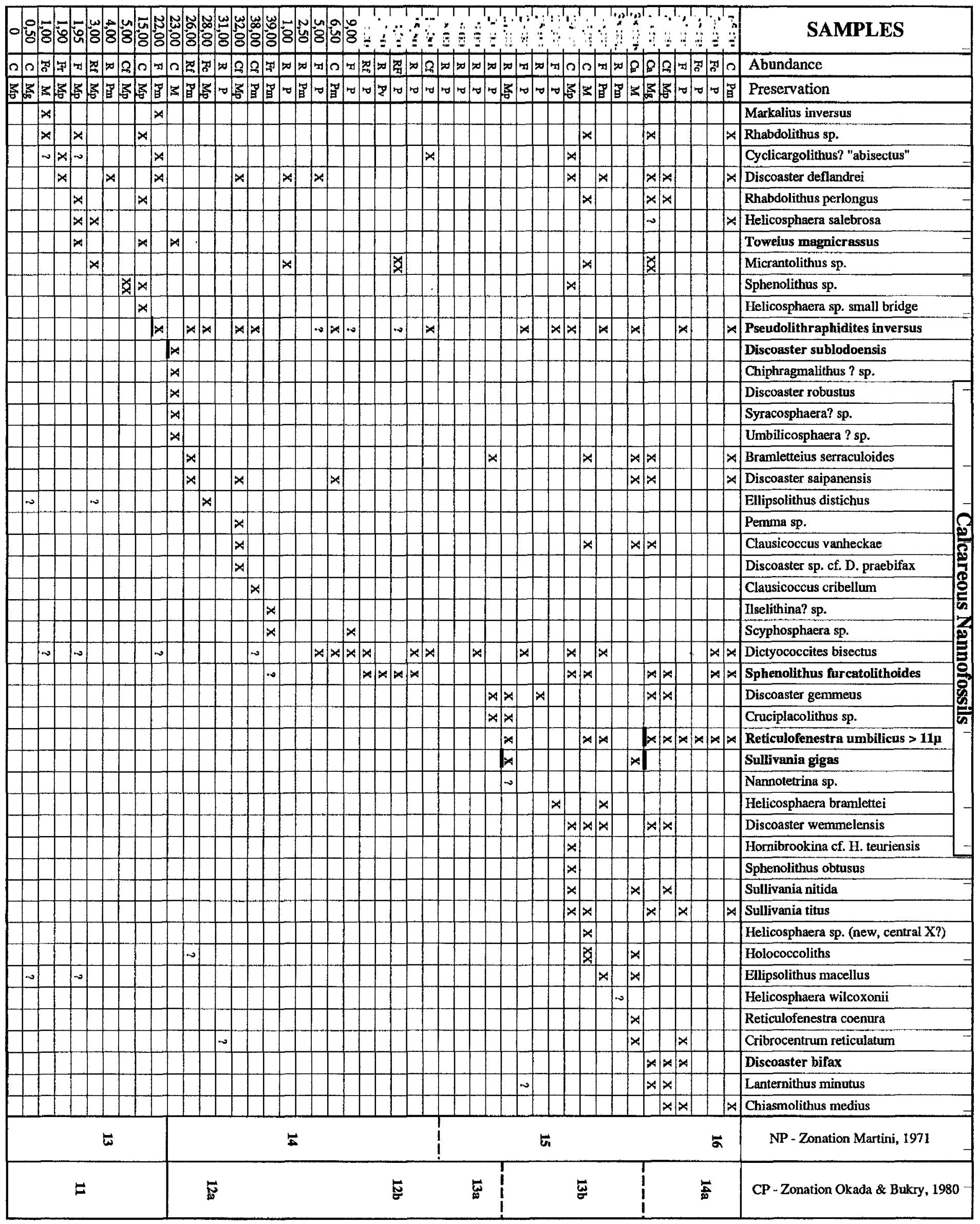



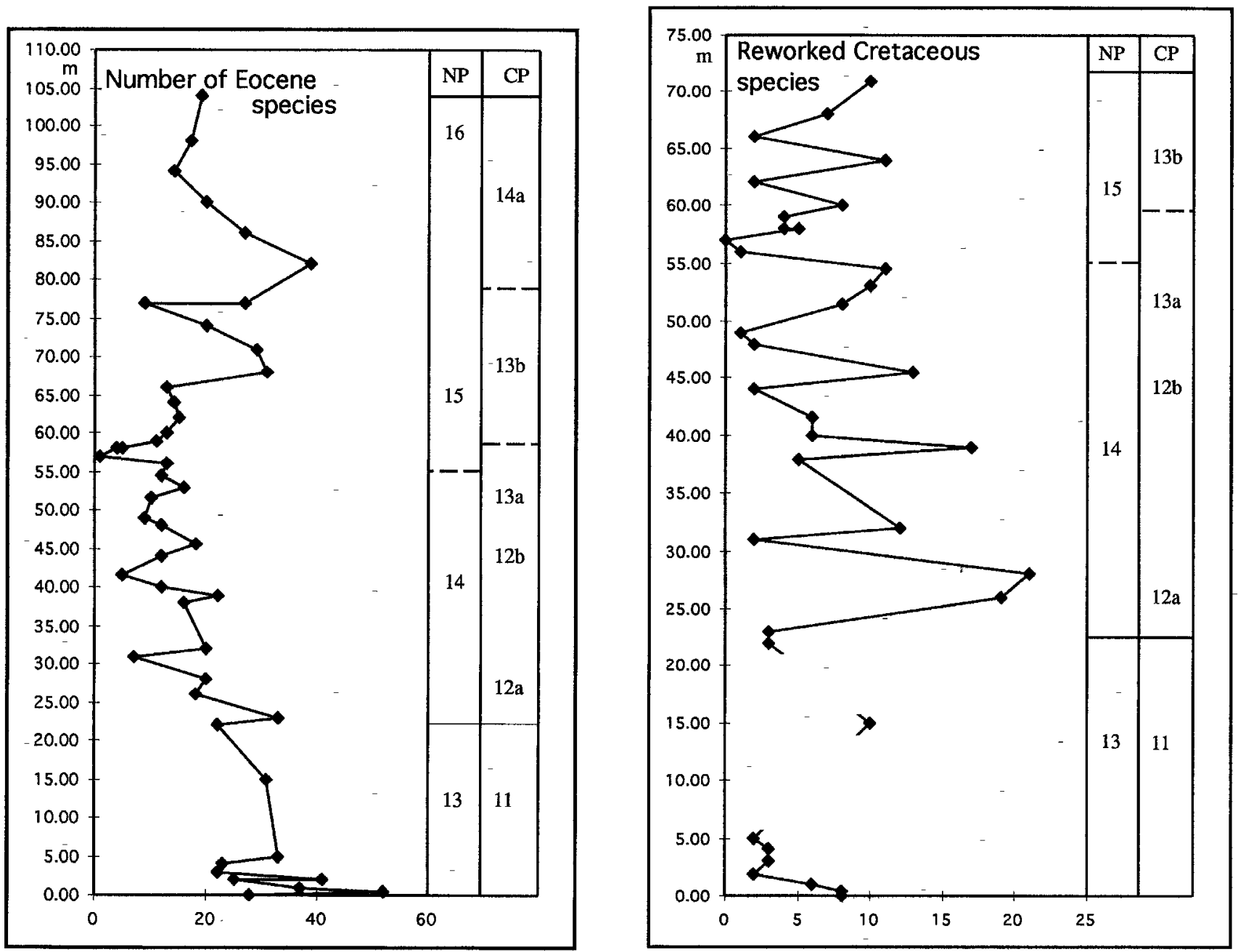

Fig. 5. - Calcareous nannofossil number of autochtonous (a) and reworked (b) species.

Nombre de nannofossiles calcaires autochtones (a) et remaniés(b).

genus not restricted to but most commonly found in Lower Cretaceous sediments. Reworking from Upper Cretaceous sediments is mainly represented by $\mathrm{Mi}$ cula decussata (Coniacian through Maastrichtian), Lithraphidites quadratus (Maastrichtian) and Microrhabdulus attenuatus (Santonian through Maastrichtian) and Arkhangelskiella cymbiformis (Campanian and Maastrichtian). Reworking from the Upper Cretaceous was nearly absent in the interval between samples 1 and 27 .

The number of species varied greatly among samples and partly depended on the state of preservation of the assemblage and the time spent searching for rare species. Fig. 5a shows the number of probable in situ Eocene species and reworked Cretaceous species (Fig. 5b). Here an interesting pattern can be observed : many in situ species were accompanied by low numbers of reworked species and some of the low in situ numbers by low numbers of reworked species. This may mean that : a) high Eocene and relatively high Cretaceous diversity is mainly the result of good preservation (which also entices the observer to look for more species...), or b) when preservation is poor, both Eocene and Cretaceous coccoliths are not very diverse and only solution resistant species are found. Comparing these findings with the lithology, it seems that samples close to calcarenite benches have low diversity and those from a softer interval between these benches have a higher diversity.

As deduced from fig. 3 and 4 , new species appear and old species disappear at a relatively high rate in 
the lower and upper part of the section, while the middle part of the section is marked by low change. This is the same interval where Upper Cretaceous reworked coccoliths are absent (except in one sample) and extends for $\pm 10 \mathrm{~m}$ on either side of the major limestone band in the section.

\section{LARGER FORAMINIFERA}

Larger foraminifera were abundant at intervals around $0,59,78$ and 109 meters, where they may be a few centimetres in diameter. Most were concentrated at the base of the turbidites and were not cemented. The different species represented include the genera Nummulites, Assilina, Discocyclina and Nemkovella.

Larger foraminifera at Agost were first studied by Von Hillebrandt (1974) who distinguished three different assemblages across the Early - Middle Eocene transition but did not classify the genera and species. Nummulites and Assilina were studied in detail by Isuman (1983) who first correlated the planktic foraminiferal biozonation of Von Hillebrandt (1974). Nummulites manfredi, the fossil index of Schaub (1981), was not found in the upper part of the Lower Eocene but Nummulites campesinus was identified in an assemblage containing Nummulites praelorioli, Nummulites polygyratus, Assilina maior and Assilina cuvillieri. The sandy interval deposited during the Early - Middle Eocene transition contained only small Nummulites and the barren interval above it was correlated with the planktic foraminiferal Hantkenina aragonensis Biozone of Von Hillebrandt (1974). Nevertheless, Nummulites of several centimetres in diameter were abundant at meter 59 (in the middle of the Hantkenina nuttalli Subzone). Isuman (1983) does not report Nummulites laevigatus at these levels but Nummulites obesus, Nummulites praelorioli and Assilina cf. exponens are frequent. In the upper part of the section, Nummulites beneharnensis was found in an assemblage with Nummulites ef. praeaturicus, Nummulites boussaci, Nummulites aff. alponensis and Assilina spira (Fig. 6).

Orthophragminids have not been studied in detail although they are frequent and well preserved. Their tests are extremely thin and saddle-like shapes are very common. The test shape suggests they used to live in the deeper part of the photic zone, in microenvironments with reduced light, provoked by terrigenous input or nannoplankton blooms. The specimens were reworked since they were hored by some organisms and the tubes were infilled with sparitic matrix and occasionally biomicrites (small nummulitids, globigerinids and corallinaceans) and some specimens were encrusted.

We collected orthophragminids at two levels (meters 0 and 78). The older assemblage was sampled at the base of the section in the planktic foraminiferal Acarinina pentacamerata Subzone, and contained Discocyclina augustae sourbetensis and Nemkovella rota. Discocyclina augustae sourbetensis ranges from "Cuisian" (Middle to Upper Ypresian) to Lower Lutetian (Less 1987, 1998). Nemkovella rota is attributed to the Middle Ypresian (Less, 1998).

The younger Orthophragminids assemblage was sampled in the upper part of the section at the base of the planktic foraminiferal Globigerapsis subconglobata Subzone. It had a diverse number of species, which could be due to intensive sampling. We found Discocyclina archiachi archiachi, Discocyclina archiaci bartholomei, Discocyclina dispansa taurica, Discocyclina dispansa hungarica and Discocylina aaroni. According to Less $(1987,1998)$ some of these species already appear in the upper Ypresian but the assemblage is characteristic of the Middle Lutetian.

According to the biozonation in Less (1987, 1998) and the correlation with the nannofossil biozonation, Orthophragminidal Zones 6 and 10 could be represented in the Agost section. By correlation, the older assemblage could correspond to Zone 6 and the younger assemblage to Zone 9 (Middle Lutetian). According to Less $(1987,1998)$, the assemblage from the sample of the upper part of the section is characteristic for the Middle Lutetian. These biozones correspond to Zones SBZ12, SBZ13 and SBZ14 in Serra-Kiel et al. (1998).

\section{DISCUSSION AND CONCLUSIONS}

The $112 \mathrm{~m}$ thick Lower and Middle Eocene sediments at Agost consisted of marls with interbedded calcarenites and detrital layers in the middle part. They were deposited in a hemipelagic environment receiving turbidites containing larger foraminifera. While the planktic foraminiferal record and zonation were good, the zonation with calcareous nannofossils and larger foraminifera were not ideal.

The study of planktic foraminifera, calcareous nannofossils and large foraminifera was based on the same samples for the first two groups and on four sampling sites for the last. It provided a biostratigraphic framework to discuss the suitability of the Agost section as a GSSP. 


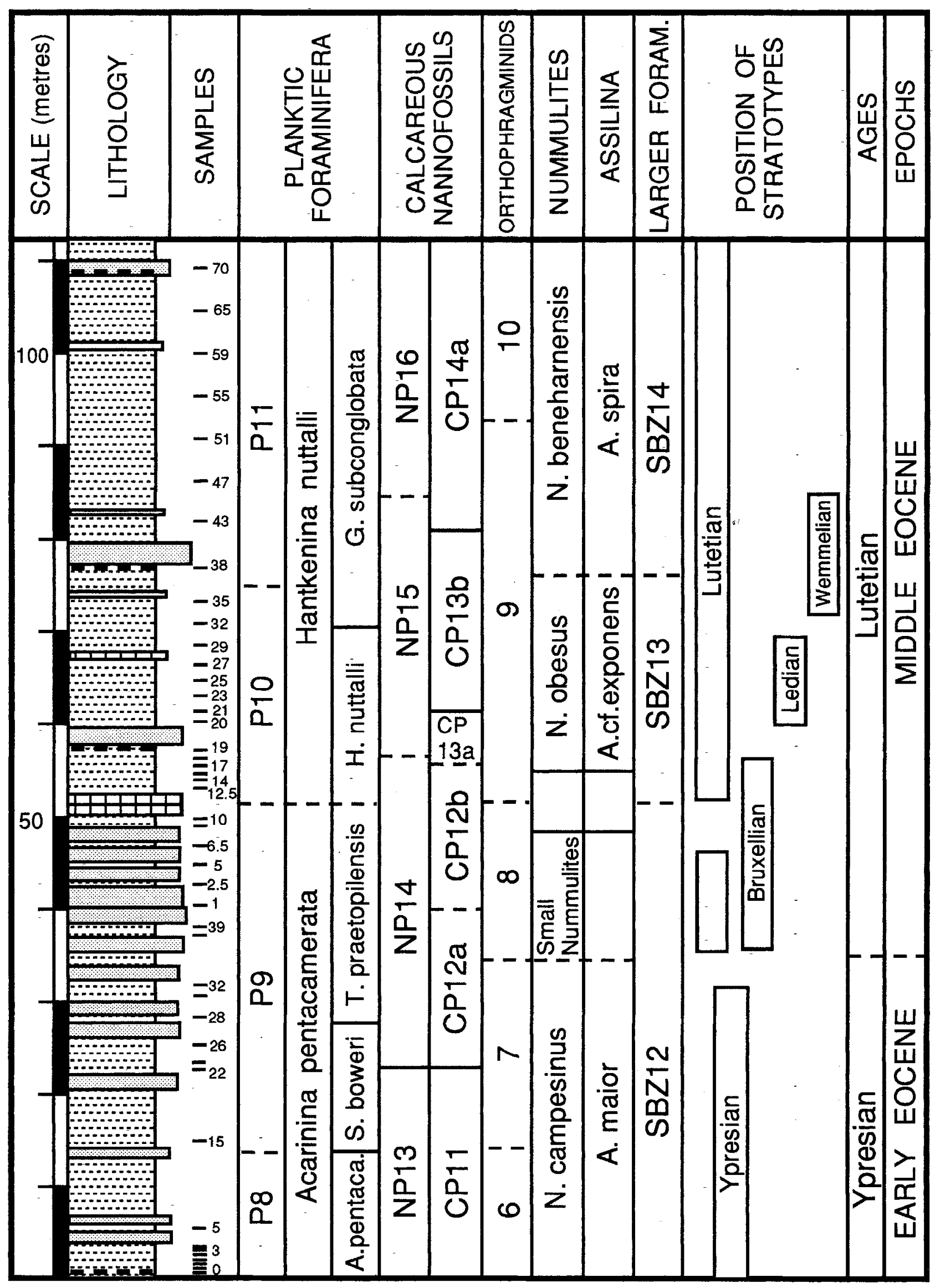

FIG. 6. - Integrated biostratigraphy and chronostratigraphy of the $\Lambda$ gost section. Biostratigraphie intégrée et chronostratigraphie de la coupe d'Agost. 
It was difficult to correlate our Agost biozonations and the stage stratotypes in Belgium and Paris basins due to their poor pelagic fossil record. Large parts of these basins also appear to have a hiatus of nearly 2 million years between the Ypresian and Lutetian, although more continuous sections occur across the French-Belgian frontier (Nolf and Steurbaut, 1990 ; Hooyberghs, $1992 ;$ 1999). The Ypresian seems to cover up to the lower part of Zone NP14, which corresponds to a level within Zone P9. The Bruxellian belongs to the upper part of Zone NP14 and seems to include parts of Zone P9 and the lower part of Zone P10 and correlates with the base of the Lutetian. According to Hooyberghs (1992), the Brussel Sand Formation (=Bruxellian of previous authors) at St.-Stevens-Woluwe (Belgium) can be assigned to Zone P9. Planktic foraminiferal markers do not seem to be present in Belgium and nannofossils indicate the upper part of Zone NP14 (Steurbaut, pers. comm.). Nevertheless, in the Mont-des Recollets at Cassel (France) the Brussels Sands are dated as Zone P10 (Hooyberghes, 1999).

The base of the Lutetian defines the Early/Middle Eocene boundary (Jenkins and Luterbacher, 1992). The Lutetian was defined by De Lapparent in 1883 and revised by Blondeau (1981) who proposed a new stratotype $50 \mathrm{~km}$ North of Paris. Calcareous nannoplankton is present in the new stratotype and spans the upper part of Zone NP14 to the lower part of Zone NP16 (Aubry, 1983). Planktic foraminifera are infrequent and not typical although the P10, P11 and P12 Zones of Blow (1979) (Bignot and Le Calvez, 1969 ; Hooyberghs, 1992 ; 1999) can be recognised. The Ledian and Wemmelian are regional stages formerly used in Belgium and both belong to Zone NP15 (Martini, 1971; Cavelier and Pomerol, 1986; Steurbaut, 1986).

The Lower/Middle Eocene boundary is usually placed at the base of the $H$. nuttalli Zone, at the FO of the marker species (Cavelier and Pomerol, 1986; Berggren et al., 1995). This event occurs at about 52 meters in Sample 12.5 in marls just above the thickest limestone bank of the section. Calcareous nannofossils seems to correlate with the upper part of Zone NP14, similar to Berggren et al. (1995). Although there are three planktic foraminifera $\mathrm{FO}^{\prime} \mathrm{s}$ at this level, the level fell in the "low change interval » of the calcareous nannofossils and no FO or LO was observed. The three FO's were at the top of an approximately $25 \mathrm{~m}$ interval, with only one new species and three disappearances. After these three incoming species at the base of the $H$. nuttalli Zone, six new species came in during the time of deposition of the next $20 \mathrm{~m}$ (the $H$. nuttalli Subzone) while only two disappeared. Three or four new forms of calcareous nannofossils appeared in the middle of the latter interval and the same number disappeared. Above the $H$. nuttalli Subzone, about 12 new calcareous nannofossil species appeared over about $30 \mathrm{~m}$ while some 26 old ones disappeared over the same interval.

The boundary between the Lower and Middle Eocene, if placed at the usual level - at the base of the $H$. nuttalli Zone, at the FO of the marker species - coincides with a level marked by the two additional FO's of planktic foraminifera. Since there is a facies change from a limestone bank to marls just below the FO of $\mathrm{H}$. nuttalli, there is a chance that the FO's of three species at the same level also implies a short hiatus at this lithological boundary. Nevertheless, there is no indication of a major hiatus in the planktic foraminiferal biozonation nor in the calcareous nannofossil assemblages which are, however, generally poorly preserved in the interval just below and above the limestone bed below the proposed boundary. Two other levels marked by major microfossil changes appear between samples 22 and 26 at the S.boweri/T.praetopilensis subzonal boundary (close to the NP13/NP14 zonal boundary) and samples 38 and 43 at CP13b/CP14a. They are not very relevant however and fall in the Upper Ypresian and Lower Lutetian stages respectively (Fig. 6).

\section{ACKNOWLEDGEMENTS}

Comments from the referees Hanspeter Luterbacher, Kàroly Sztràkos and Etienne Steurbaut improved the manuscript. The authors also wish to thank Morris Villarroel and Martine Acena for English and French corrections. Support for the research was provided by DGES project PB97-1016.

\section{BIBLIOGRAPHY}

Aubry M.P. (1983) : Biostrathgraphie du Paléogène épicontinental de l'Europe du Nord-Ouest. Euude fondée sur les nannofossiles calcaires. Doc. Lab. Géol. Fac. Sci. Lyon, vol. 89, 320 p.

Aubky M.P. (1989) : Handbook of Cenozoic Calcareous Nannoplankton. Book 3. Micropal. Press, New York, 279 p.

BergGren W.A., Kent D.V., Swisien C.C. and Aubry M.A. (1995) : A revised Paleogene geochronology and chronostratigraphy. In Berggren, W.A., Kent, D.V. and Hardenbol, J., eds. Soc. Econ. Geol. Paleont. Spe. Public. Tulsa. p. 129-212.

Bignot G. and Le Calvez Y. (1969) : Contribution à l'étude des Foraminifères planctoniques de l'Éocene du Bassin dc Paris. 
Proc. First Int. Conf. Plankt. Microf., Genève 1967, vol. 1, p. 161-166.

Blondeau A. (1981) : Lutetian. Bull. Inf. Géol. Bassin Paris, Mém. 2, p. 167-180.

BLow W.A. (1979) : The Cainozoic Globigerinida. E.J. Brill, Leiden, 3 vol., $14.13 \mathrm{p}$.

Cavelier C. and Pomerol CH. (1986) : Stratigraphy of the Paleogene. Bull. Soc. géol. France, Paris, vol. 2, p. 273-276.

Colom G. (1954) : Estudio de las biozonas con foraminíferos del Terciario de Alicante. Bol. I.G.M.E., Madrid, vol. 66, 279 p.

Cremades J. (1982) : Contribución al conocimiento de los foraminíferos planctónicos y al estudio bioestratigráfico del Eoceno y Oligoceno del sector oriental de las Cordilleras Béticas. Tesis Doct. Univ. Granada, vol. 359, 331 p.

Gonznlvo C. and Molina E. (1998) : Planktic foraminiferal biostratigraphy across the Lower-Middle Eocene transition in the Betic Cordillera (Spain). N. Jb. Geol. Paläont. Abh., Stuttgart, vol. 11, p. 671-693.

Hoovbergis H.J.F. (1992): A new dating of the Brussels Sand Formation (Lower-Middle Eocene) on planktonic foraminifera from St-Stevens-Woluwe and Neerijse, Belgium. Tertiar. Res., London, vol. 14, p. 33-49.

Hooyberghs H.J.F. (1999) : Foraminifera of the Lower to Middle Eocene deposits in the Mont-des-Récollets at Casel (N.France). Aardk. Mededel. vol. 9, p. 147-152.

ISUMAN N. (1983) : Mikropaläontologische Untersuchungen von Grossforaminiferen (Nummuliten und Assilinen) in Alttertiär von Südostspanien (Aspe und Agost in der Provinz Alicante). Berliner geowiss. Abh. A., Berlin, vol. 49, p. 61-170.

JeNKıNs D.G and Luterbacher H. (1992) : Paleogene stages and their boundaries (Introductory remarks). N. Jb. Geol. Paläont., Abh., Stuttgart, vol. 186, p. 1-5.

LEss G. (1987) : Paleontology and stratigraphy of the European Orthophragminidae. Geol. Hung. ser. paleont., Budapest, vol. $51,1373 \mathrm{p}$.

Less G. (1998) : The zonation of the Mediterranean Upper Paleocene and Eocene by Orthophragminidae. DELA-Opera SAZU 4 razr. Ljubljana, 34, 2, p. 21-43.

Marquez L. (1975) : Microbioestratigrafía del Paleógeno de la zona Este de la Provincia de Alicante. Tesis Licenciatura. Univ. Madrid. (unpublished).

Marquez L. (1983) : Estudio de algunos aspectos paleohiológicos, sistemáticos y hioestratigráficos de los foraminúferos del Eoceno inferior de la zona central de la provincia de Alicante. Tesis Doct. Univ. Madrid, $177 \mathrm{p}$.

Marquez L. (1991) : El Eoceno inferior y Medio de Agost (Provincia de Alicante). Rev. Esp. Paleont., Madrid, $\mathrm{n}^{\circ}$ Extra, p. 197-204.
MARQUEZ L. and USERA J. (1984) : Bioestratigrafía (foraminíferos) del Eoceno de la localidad de Agost (Provincia de Alicante). Act. Geol. Hisp., Madrid, vol. 19, p. 19-28.

MarTini E. (1971) : Standard Tertiary and Quaternary calcareous nannoplankton zonation. In Farinacci, A. (Ed.) Proc. 2nd Plankt. Conf., Roma, vol. 2, p. 739-785.

Nolf D. and Steuhbaut E. (1990) : Stratigraphie de l'Eocène en Flande occidentale et dans les régions limitrophes. Bull. inf. Géol. Bassin Paris, Paris, vol. 27, fasc. 3, p. 9-36.

OKADA H. and BUKRY D. (1980) : Supplementray modification and introduction of code numbers to the low-latitude coccolith biostratigraphic zonation: Marine Micropal., Amsterdam, vol. 5 , p. 321-325.

Perch-Nielsen K. (1985) : Cenozoic calcareous nannofssils. In Bolli, H.M., Saunders, J.B. and Perch-Nielsen, K. (Eds) : Plankton Stratigraphy, Cambridge University Press, p. 427554.

Schuub H. (1981) : Nummulites et Assilines de la Téthys paléogène. Taxinomie, phylogenèse et biostratigraphie. Mém. Suiss. Paléont., Basel, vol. 104-105, 236 p.

Serra-Kiel J., Hotttnger L., Caus E., Drobne K., Ferrandez C., Jauhri A.K., Less G., Pavlovec R., Pignatti J., Samso J.M., Haub H., Sirel E., Strougo A., Tambareau Y., TosQUELLA J. and ZAKREvSKAYA E. (1998) : Larger foraminiferal biostratigraphy of the Tethyan Paleocene and Eocene. Bull. Soc. géol. France, Paris, vol. 169, p. 281-299.

Steunbaut E. (1986) : Late Middle Eocene to Middle Oligocene calcareous nannoplankton from the Kallo well, some boreholes and exposures in Belgium and a description of the Ruisbroek Sand Member. Contr. Tert. Quat. Geol., Leiden, vol. 23, n. 2, p.49-83.

Steurbaut E. (1988) : New Early and Middle Eocene calcareous nannoplankton events and correlations in middle to high latitudes of the northern hemisphere. Newsl. Stratigr., Leiden, vol. 18, p. 99-115.

Von Hillebrandt A. (1974) : Bioestratigrafía del Paleogeno en el Sureste de España (Provincias de Murcia y Alicante). Cuad. Geol., Granada, vol. 5, p. 135-153.

Von Hillebrandt A. (1976): Los foraminíferos planctónicos, nummulítidos y cocolitofóridos de la zona de Globorotalia palmerae del Cuisiense (Eoceno inferior) en el SE de España (Provincias de Murcia y Alicante). Rev. Esp. Micropal., Madrid, vol. 8, p. 323-394.

WEI W. and WISE S.W. (1989) : Paleogene calcareous nannofossil magnetobiochronology : Results from South Atlantic DSDP Site 516. Marine Micropal., Amsterdam, v. 14, p.119-152. 